\title{
The Effectiveness of Principal Leadership Styles in Crisis Management
}



1 State University of Malang, Faculty of Education, Department of Educational Administration, East Java, Indonesia, ekonurhajila@yahoo.com

2 State University of Malang, Faculty of Education, Department of Educational Administration, East Java, Indonesia, a.supriyanto.fip@um.ac.id

3 State University of Malang, Faculty of Education, Department of Educational Administration, East Java, Indonesia, mustiningsih.fip@um.ac.id

4 State University of Malang, Faculty of Education, Department of Educational Administration, East Java, Indonesia, zummydami82@gmail.com

Annotation. The research aimed to explore the types of effective principal leadership styles in crisis management at school. Data analysis using structural equation modeling. The results showed that transformational leadership had a strong positive effect on crisis management, charismatic leadership and transactional leadership had a positive but weak effect on crisis management. In contrast, entrepreneurial leadership had a negative but weak effect on crisis management.

Keywords: charismatic leadership, entrepreneurial leadership, transformative leadership, transactional leadership and crisis management.

\section{Introduction}

The COVID-19 pandemic has rendered the contemporary world almost entirely unpredictable. The large numbers of victims and the varied socio-economic impacts have made people more worried, especially given the speed with which the virus spread around the world. The entire social structure is scientifically dealing with COVID-19, treating its victims, and working to return to post-pandemic conditions as quickly as can safely be achieved. These actions are not merely carried out in the health sector but in many others: social, cultural, educational, political, legal, security, and so on (Hidayat et al., 2020). 
In education, the COVID-19 pandemic has wreaked havoc on the very structure of education (Hargreaves \& Fullan, 2020). In the face of that turmoil, quick decisions and effective solutions are required to prioritize the welfare of leaders, teachers, students, families, and all other stakeholders involved in restarting school activities (Harris \& Jones, 2020). Teachers must carry out their pedagogical and assessment duties using alternative methods (König et al., 2020). Students must also adapt, whether they are able to learn enough at home through online classes or need a combination of in-person and remote learning to obtain a satisfactory learning experience (Dwivedi et al., 2020). COVID-19 led to the emergence of new schools without standardized leadership, preparation or development, inspection framework, key performance indicators, or benchmarks (Harris \& Jones, 2020). These conditions led to new patterns of work in education (Dwivedi et al., 2020).

Responding to the COVID-19 crisis was not only necessary but also urgent. Comprehensive handling is called crisis management (Hidayat et al., 2020). In schools, a crisis is an urgent situation that requires school leaders to take quick and decisive action (Smith \& Riley, 2012). The three key components that define a crisis are: (1) threats to an organization's high-priority values; (2) several castings and limited time for optimal responses; (3) and unexpected responses (Bowers et al., 2017; Williams et al., 2017). The organization needs to take several actions: define the assessment process of risk, which enables understanding the overall threat, the vulnerability of critical activities, and potential sources of supports (Hamidovic, 2012); analyze the cause, understand the consequences, grasp the crisis prevention strategy, and adjust the normalization point (Shrivastava et al., 2013); and, eventually, restore the system to alignment (Williams et al., 2017).

The type of behavioral leadership is important in determining an organization's performance (Teo et al., 2017). Each leadership style has been mapped through a variety of approaches using different classifications and categories, with different leadership styles of leadership most effective in different situations (Bowers et al., 2017). Leaders need to focus on this issue in their own organization. They must have special skills to prepare, manage, and find solutions to possible crises that threaten their organization's existence (Harwati, 2013). Schools are no exception to this general rule, and the details of crisis management in an educational leadership contexts need to be further investigated. The present study addresses four leadership styles: charismatic, entrepreneurial, transformative, and transactional. The reason for those choices is that they are the four most commonly used leadership styles in education. Based on the research focus, this study aimed to identify and exploit leadership types that are most effective in crisis management. This research can help determine which leadership styles have significant positive effects on crisis management. The research questions are as follows:

1. Is there any significant relationship between charismatic leadership and crisis management? 
2. Is there any significant relationship between entrepreneurial leadership and crisis management?

3. Is there any significant relationship between transformative leadership and crisis management?

4. Is there any significant relationship between transactional leadership and crisis management?

5. Which leadership type has the strongest relationship to crisis management?

There are many definitions of leadership, and writers use their own perspectives and their view of the most interesting phenomena to define leadership. Theories of leadership styles have been developed (Bass \& Avolio, 1994), and leadership is the most significant branch of management studies (Weihrich et al., 2008). It is a reciprocal process of social effects (Jeremy, 2012; Silva, 2016). In the educational context, leadership influences teachers, students, and other stakeholders and is not limited to a single person. Ideally, the influencing process should lead to a climate of effective learning experiences that create value-added responses to all stakeholders' interests and keep all the organizations in schools (monitoring the learning process, managing personnel, allocating resources, and so on) running smoothly (Daniels et al., 2019).

This type of leadership is a combination of various traits, characteristics, and behaviors used by a leader to collaborate effectively with those being led (Jeremy, 2012) to achieve organizational goals (Alzoubi \& Jaaffar, 2020). Leadership styles can contribute effectively to determining organizational performance (Al Khajeh, 2018). Contingency theory explains that not all leaders may have the same level of skills and competencies when facing a crisis or challenging environment (Taormina \& Taormina, 2008). This research's leadership styles are charismatic, entrepreneurial, transformative, and transactional Leadership in dealing with the crisis, as shown in Figure 1.

Charismatic leaders are good at inspiring followers to speak optimistically about what needs to be achieved in the future and instilling in their followers' positive ideals associated with desired outcomes (Shao et al., 2017). Using evolutionary psychology terminology, the writer defines charismatic leadership as a signaling process in which a leader conveys his or her ability to solve pressing challenges of coordination and cooperation in groups. This process is context-dependent but essentially consists of: (1) drawing attention to recruiting followers; (2) harnessing the extraordinary abilities of rhetoric and knowledge of cultural symbols and rituals to inspire and offer a vision; (3) minimizing perceived risk and cooperation; and (4) aligning these followers towards common goals (Grabo \& Van, 2016). There are four aspects in this style: (1) individual traits, it is the unique set of skills and abilities the leader possesses; (2) follower behavior, it is how and why followers are motivated; (3) organizational or contextual influence, it is the extent to which the leader interacts with the needs of followers and organizational goals; (4) results, it is linking leader's charisma to measures of success such as increased team productivity or job satisfaction (Grabo et al., 2017). 
The concept of transformative leadership systematically attempts by leaders to transform members to share organizational goals from desires in themselves. This behavior is characterized by transformational behavior because leaders are expected to see a clear vision as an important driver of unselfish employee action (Jensen et al., 2016). Transformational leadership focuses on developing teams and taking their needs into account. Leaders who focus on transformational leadership focus primarily on developing a system of values, morality, skills, and team members' motivation levels (Al Khajeh, 2018). Transformational behavior is essentially developed into four characteristics; idealized organizational influence, inspirational motivation, intellectual stimulus, and individual attention (Cho et al., 2019).

Transactional leaders are always willing to give something in return (Al Khajeh, 2018). It can include several things like promotions, raises, performance reviews, extra responsibilities, etc. This leadership strategy conceptualizes behavior that seeks to meet employees' higher needs to involve them in achieving organizational goals (Jensen et al., 2016). Higher employee perceptions of aid and fairness in the organization through leaders' transactional behavior increase their affective organizational commitment (Cho et al., 2019).

Entrepreneurial leadership helps create an encouraging atmosphere to change and innovate in schools (Wahab \& Tyasari, 2020). It will achieve the mindset of entrepreneurial leadership through the development of strategic resource management. Entrepreneurial thinking and the ability to manage strategic resources will increase creativity and innovation to positively impact organizational performance (Agung et al., 2020). He then separated this leadership style into four dimensions: explorers, miners, accelerators, and integrators. It aims to combine these dimensions with "general entrepreneurial leadership behavior (Pihie, 2017).

\section{Crisis Management}

A crisis is an abnormal, unstable, and complex situation that inherently represents a threat to an organization's strategic objectives, reputation, or existence. It can cause financial loss and damage the organization's reputation, whether physical, financial, or emotional (Salvador et al., 2017), and routine procedures cannot resolve it. A crisis is not identically an incident, and some argue their management presents special challenges requiring a different approach (Hamidovic, 2012). Thus, understanding, managing, and intervening in a crisis is a critical challenge for all stakeholders involved. To capture crisis management and organizational response nuances, it is helpful to look at crisis management from a multi-level and multidisciplinary perspective, including the individual, organizational, and institutional levels (Liu \& Froese, 2020).

The attributes and skills needed for school leadership in crisis are fundamentally different from management in a regular school environment. It is associated with strong school leadership in dealing with events, emotions, and consequences in the upcoming 
times by minimizing personal and organizational harm to the school and community. Crisis in many forms is bound to occur in schools, no matter how well they are led and managed. Many crises occur without any warning; others gradually emerged. Some crises can be resolved quickly, while others can take a longer time (Smith \& Riley, 2012)

There is very little literature for this paper, either books or academic articles, specifically the examples of crises in schools and their communities. However, Whitla's Crisis Management and the School Community has provided a series of real-life school-based case studies to understand the nature of school-based crises. The cases offered such as a teacher who commits suicide in school; four students died in a car accident; serious gang fights at school; teachers fired and then threatened their schools with bombs; student who was kidnapped; students killed on their way home from school; the fire that burned many schools; a student who accidentally drowned in a school camp; someone with a gun holding a teacher and two students' hostage; and a student got lost in the snow on a school trip (Whitla, 2003). Another study also revealed that crisis management in schools related to the main driving factor that causes schools to fail to deal with crises. It is schools where they cannot catch early warning signals of a crisis, the inability or reluctance of leaders to see the world objectively and change the culture. School organization to align with new realities (Murphy \& Meyers, 2009). In this study, the crisis that occurred is the impact of the COVID-19 pandemic, which had brought chaotic situation and required new methods of school to survive (Dwivedi et al., 2020).

Components in crisis management include preparing for crises, facing crises, and recovering from the crisis. Preparing for a crisis is preparation for facing a crisis by involving the construction and consideration of various relevant scenarios. Responding to a crisis is a second thing done in several stages; get the facts, implement relevant contingency plans, or quickly adapt to deal with the current situation, be assertive, show concern, and communicate. The next thing is to recover from the crisis. After a crisis, everything needs to get back to 'normal' as fast as possible (Smith \& Riley, 2012).

Crisis management builds on and complements emergency management routines and structures, and it is also providing selective adaptation to the specific circumstances of a crisis or disaster (Van \& Kapucu, 2011). Leadership in crisis is how a leader prepares himself for fast change and reacts decisively and appropriately (Smith \& Riley, 2012). Leaders must work together and communicate crisis management both internally and externally (Taneja et al., 2014).

Based on the review of related literature, the conceptual framework proposed to test the hypothesis can be illustrated in Figure 1. 
Figure 1

Conceptual Framework of the Study

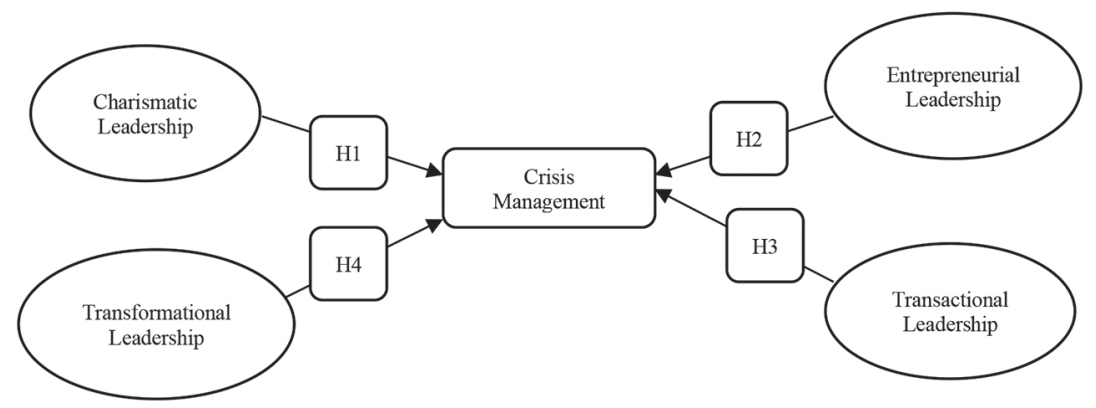

\section{Methodology}

Research Population and Sample: the study's population comprised teachers and teaching staff at the junior and senior high school levels at the Thursina International Islamic Boarding School with 325 people. The research sample was selected by systematic random sampling of 100 people. The demographics sample consists of 61 men (61\%) and 39 (39\%) women. The respondents were 78 people (78\%) teachers and $22(22 \%)$ teaching staff from the work type. Based on the working years, 33 people (32\%) were over five years, and 67 people (67\%) were under five years). The data were collected in September 2020.

Instruments of Data Collection: This study developed a questionnaire with a validation test. It comprises two major parts; the first part includes three personal information questions for each participant: age, sex, and length of work. The second part of the survey comprised 35 indicators for all variables. Each instrument was adopted and developed from theory and its context; charismatic leadership (Lovelace et al., 2018), (Grabo et al., 2017), (Javidan \& Waldman, 2003), entrepreneurial leadership (Thornberry, 2006), (Wahab \& Tyasari, 2020), (Mitchelmore \& Rowley, 2009), (Pihie, 2017), (Esmer \& Dayi, 2016), transformative leadership (Iii et al., 2018), (Jensen et al., 2016), (Turnnidge \& Côté, 2016), transactional leadership (Jensen et al., 2016), (Oterkiil \& Ertesva, 2014), and crisis management (Smith \& Riley, 2012), (Bundy et al., 2016).

This study investigated four leadership styles: charismatic leadership, entrepreneurial leadership, transformative leadership, and transactional leadership as an independent factor and crisis management as a dependent factor. Participants were asked to rate how important each item was according to a 5-point scale, starting from point 1, which strongly disagree, to point 5 , which strongly agree.

Data Analysis: Data analysis using structural equation modeling with Smart PLS-SEM 3.0. and processed in two stages. The first stage evaluated the measurement model (other 
models), consisting of convergent validity, discriminant validity, consistency reliability, convergent validity, and discriminant validity (Hamid et al., 2019).

The second stage was the evaluation of the structural model (inner model), there are several criteria in the assessment of the structural model: (1) to measure the significance by using a significant value, the $t$-value must be greater than 1.96 and $p$ must be less than 0.05 (Hair et al., 2014), (2) Analysis of the coefficient of determination (R-Square), which is to show the ability of how much exogenous or independent variables are in predicting endogenous or dependent variables and showing the strength of the model made, according to (Wynne, 1998) R2 values of $0.67,0.33$ and 0.19 were assessed as substantial, moderate and weak, and (3) Path Coefficient values that indicate the direction of the relationship between variables and the significant magnitude of the influence of each variable. According to (Cohen, 1988) f-squared 0.02, 0.15, and 0.35 can be assessed as weak, moderate, and strong effects.

\section{Results}

\section{Measurement Model (Outer Model)}

The Smart PLS 3.0 program on the PLS Algorithm measured the standard value estimation model such as loading factor, internal consistency reliability, discriminant validity, and convergent validity.

Convergent validity was used to measure the validity of the reflective indicator as a variable measure, and convergent validity can be seen from the value of the loading factor value on each variable indicator. According to (Sarwon, 2016), the outer loading value $=0.5$ can still be tolerated to be included in the model, while the outer loading value below 0.5 can be removed from the analysis. An indicator was said to have good validity if the outer loading value was above 0.70 . This research variable was developed with 35 indicators; 32 indicators had a loading factor value $>0.7$, while three indicators had a value of $<0.7$, so they were eliminated.

Based on table 1 (appendix), in general, the variables of the type of leadership and crisis management all average scores showed a high level. The following leadership styles were based on the highest rank; Transformational leadership $\mathrm{M}=(3,830$ to 4,120$), \mathrm{SD}=(0.828$ to 1,030$)$, Transactional leadership $\mathrm{M}=(3,740$ to 4,130$), \mathrm{SD}=(0.868$ to 0.963$)$, Entrepreneurial leadership $\mathrm{M}=(3,650$ to 4,110$), \mathrm{SD}=(0.782$ up to 1,052$)$, Charismatic leadership $\mathrm{M}=(3,490$ to 3,780$), \mathrm{SD}=(0,733$ to 1,052$)$ and about crisis management $\mathrm{M}=(3,510$ to $4,040), \mathrm{SD}=(0,760$ to 0,911$)$.

The internal consistency reliability and convergent validity values in table 2 were measured with the following conditions; Internal consistency was measured by an Alpha coefficient $>0.7$ (Chin, 1998) with an AVE value $>0.5$ (Hair et al., 2014) (Urbach \& Ahlemann, 2010). Therefore, the results of internal consistency reliability were acceptable. 
Table 2

Internal Consistency and Convergent Validity $(n=100)$

\begin{tabular}{lccc}
\hline \multicolumn{1}{c}{ Constructs } & Alpha & CR & AVE \\
\hline Charismatic leadership & 0.914 & 0.931 & 0.660 \\
Crisis Management & 0.896 & 0.918 & 0.616 \\
Entrepreneurial leadership & 0.916 & 0.933 & 0.667 \\
Transformational leadership & 0.895 & 0.917 & 0.613 \\
Transactional leadership & 0.873 & 0.912 & 0.721 \\
\hline
\end{tabular}

Measuring discriminant validity can be seen by using cross-loading between the indicator and the construct. In table 3 (appendix), the value of construct correlation (latent variable) on the indicator itself was higher than the correlation value for other construct indicators (latent variables). It showed that each latent construct used to predict the indicators in their respective constructs had a better value than other constructs' indicators.

To find out the strength of each indicator in measuring variables, it can be seen in Figure 2. By looking at the $\mathrm{t}$-statistics. The greater the $\mathrm{t}$-statistic, the greater the dominant indicator in measuring the variable.

Figure 2

Measurement Model

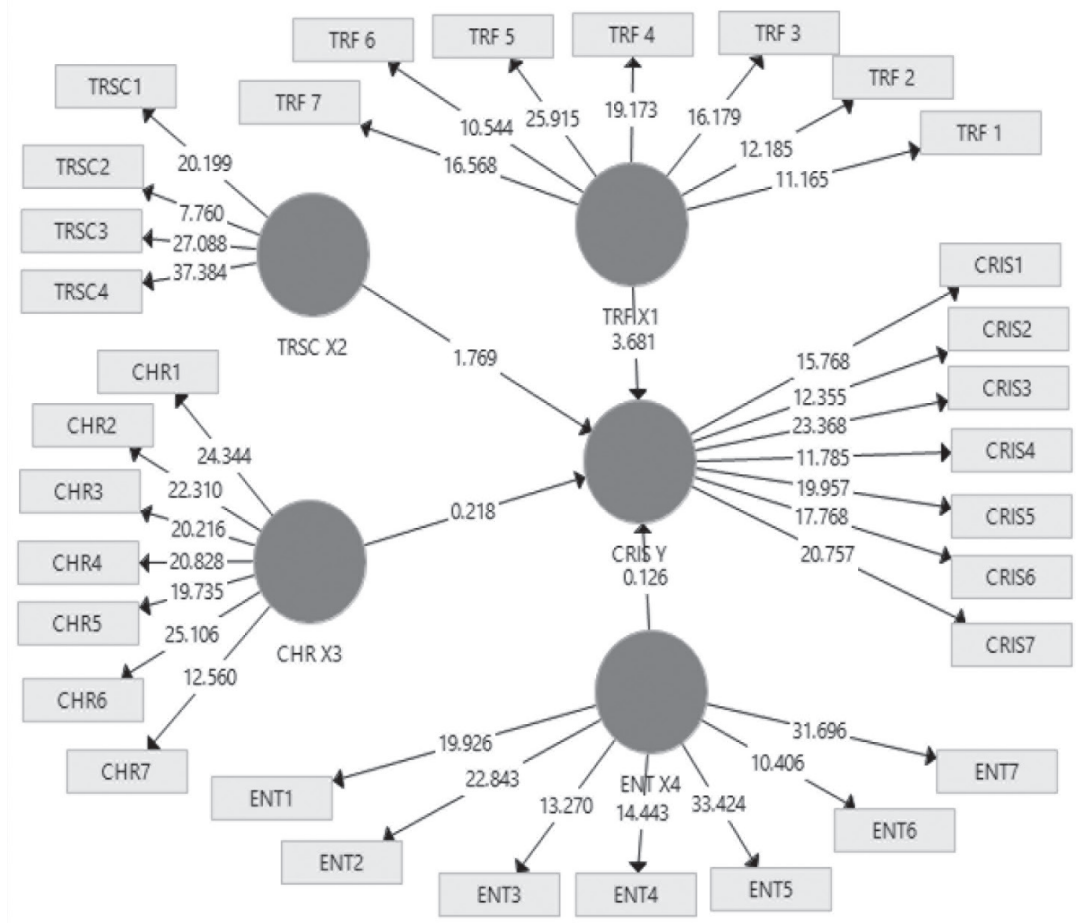




\section{Structure Model (Inner Model)}

The structural model was the stage used to test the hypothesis in this study. As stated by (Ee et al., 2013); (Sang et al., 2010), structural models show a causal relationship between constructs, path coefficients (direct effects), and non-existent specific effects (mediation effect). The $t$-value must be greater than 1.96 , and $\mathrm{p}$ must be less than 0.05 . This provision followed the guidelines used by leading researchers in their recent study (Hair et al., 2014); (Henseler et al., 2009). Table 4 showed that the Transformational leadership variable had a significant positive effect on crisis management, charismatic leadership and transactional leadership had a positive but insignificant effect on crisis management. In contrast, entrepreneurial leadership had a negative effect on crisis management.

Table 4

Structure Model Assessment Path Coefficient (Direct Effect)

\begin{tabular}{lcccc}
\hline \multicolumn{1}{c}{ Constructs } & Beta & SD & T-Value & P \\
\hline Charismatic Leadership -> Crisis Management & 0.031 & 0.141 & 0.218 & 0.827 \\
Entrepreneurial Leadership -> Crisis Management & -0.021 & 0.167 & 0.126 & 0.900 \\
Transformational Leadership -> Crisis Management & 0.466 & 0.127 & 3.681 & 0.000 \\
Transactional Leadership -> Crisis Management & 0.215 & 0.211 & 1.769 & 0.077 \\
\hline
\end{tabular}

The coefficient of determination (R2) showed the exogenous or independent variables' ability to predict the endogenous or dependent variables and show the model's strength. R2 was the best suitability value for the real empirical indicators achieved with values ranging from 0 to 1 (Hair et al., 2014). According to Falk and Miller (1992), the R-square value of 0.10 was acceptable. According to (Wynne, 1998), R2 values of $0.67,0.33$, and 0.19 were assessed as substantial, moderate, and weak, respectively. Table 5 showed that the exogenous crisis management variable had a substantial predictive value.

Path Coefficient values that indicated the direction of the relationship between variables and the significant magnitude of each variable's effect, according to Cohen (1988) f-squared $0.02,0.15$, and 0.35 , respectively, can be assessed as weak, moderate, and strong. Table 5 showed that transformational leadership had a powerful effect on crisis management, charismatic leadership, and transactional leadership had a weak effect on crisis management. In contrast, entrepreneurial leadership had a negative but weak effect on crisis management. 
Table 5

Predictive Relevance (R2) and Effect Size (f2)

\begin{tabular}{lcc}
\hline \multicolumn{1}{c}{ Relationship } & F2 & Range \\
\hline Charismatic Leadership -> Crisis Management & 0.031 & Weak \\
Entrepreneurial Leadership -> Crisis Management & -0.021 & -Weak \\
Transformational Leadership -> Crisis Management & 0.466 & Strong \\
Transactional Leadership -> Crisis Management & 0.215 & Medium \\
\hline \multicolumn{1}{c}{ Construct } & R2 & Range \\
\hline Crisis Management & 0.423 & Substantial \\
\hline
\end{tabular}

\section{Discussion}

The literature with various studies on effective school leadership types in facing crises is a fascinating study. The skills and attributes a school leader needs in crisis are fundamentally different from those generally required as part of a normal school environment (Smith \& Riley, 2012). It is a fascinating study on how to find out school leadership in facing a crisis. This study has compared the types of leadership in managing crises due to the impact of COVID-19 (Table 4).

Charismatic leadership on crisis management: Charismatic leadership has a positive but insignificant effect on crisis management. Charismatic leaders are good at inspiring followers, speak optimistically on what needs to be achieved in the future, and instill their followers' positive ideals associated with the desired outcome (Shao et al., 2017). Thus, organizations are more enthusiastic about individuals who carry charisma and can modify and transform organizational tactics and culture and facilitate organizations to be more flexible towards the outside environment's needs in a crisis (Ayoub, 2017). In a study (Halverson et al., 2004), a crisis can cause followers to attribute a greater level of charisma to their leader, regardless of the leader's behavior; however, the level of stress and crisis also affects the action of the leader. Another study showed that tensions and misunderstandings in understanding the critical elements of synchronizing to a crisis are an extreme concern for charismatic leadership before or even during a crisis. The leader must start by providing a clear vision of the situation more than anything. A leader must monitor, control and guide the crisis strategy (Karim, 2016).

Entrepreneurial leadership on crisis management: entrepreneurial leadership harms crisis management. The ability of entrepreneurial leadership in terms of catalyst refers to the leader's organization's behavior and how the leader indirectly encourages change and opportunities. Alternatively, they stimulate innovation, new approaches, and entrepreneurial action among their subordinates by creating a supportive environment (Pihie, 2017). It makes the leader spend more time rather than other types of leadership. Time is 
one of the most valuable resources in a crisis, and it cannot be wasted to do needs analysis (Plessis \& Keyter, 2020). One part of leadership behavior needed in facing a crisis is how strong leadership implements actions in a crisis, and timeline through a performance management scheme (Wino et al., 2020). In applying this assertive behavior, it must be precise to avoid destructive leadership. It is essential to highlight that the same type of behavior may not have the same impact in different contexts and situations. For example, a leader with fast and difficult decisions during a stressful situation can be considered constructive while the same leader can be regarded as destructive if he uses the same behavior when the case is less stressful (Fors, 2020).

Transformative leadership on crisis management: Transformational leadership has a significant positive effect on crisis management. This finding is in line with several previous studies, which examined the impact of transformational leadership on crisis management (Ayoub, 2017) (Alzoubi \& Jaafar, 2020). Transformational leadership and emotional intelligence can bring success to work in conflict situations (Alhamani et al., 2020). Likewise, when a financial crisis occurs, transformative leadership is an essential part of effective leadership (Zhang et al., 2012). Transformational leadership with effective work procedures can also improve educational institutions' overall performance in crises (Ali \& Mohammed, 2018). Transformational leadership in crisis conditions where leaders can use various mechanisms and strategic processes to improve understanding and substantive decision making, have collective support, have resilience, and build adaptive capacity when a crisis continues (Wardman, 2020).

Transactional leadership on crisis management: Transactional leadership has a positive but insignificant effect on crisis management (Table 4). The results of this study are in line with (Ayoub, 2017). Transactional leaders are responsible for enforcing routines by managing individual performance and facilitating group performance during the crisis stage. To provide returns, transactional leaders reward for excellent performance or withhold rewards such as remuneration, promotions during the post-crisis phase. Transactional leaders use rewards and punishments to gain compliance during the action stage to ensure timely, efficient, and practical implementation of mitigation strategies (Plessis \& Keyter, 2020). These leaders focus on a small set of individual details; smart, follow the rules, and get the job done. Transactional leaders are bound by rules and regulations, making them unsuitable for managing the dynamics of most crises (Bowers et al., 2017).

The strongest leadership types in crisis management: Transformational leadership has a strong relationship in crisis management, transactional leadership has a moderate relationship, and charismatic leadership has a weak relationship, and entrepreneurial leadership has a weak negative relationship (Table 5). Various factors contribute to a strong influence on transformational leadership. The leader can strive to make all members of the organization work together towards the organization's vision. This condition is closely related to how communication skills and emotional intelligence convey ideas and values to motivate to achieve organizational goals during a crisis - the suitability of values between 
the leader and group members who act as a mediation mechanism. Moreover, combined with crises, emotional control is one of two crucial factors that play a moderating role in the relationship between transformational leadership and value appropriateness between leader and members (Zhang et al., 2012). A high level of emotional intelligence is a prerequisite for strengthening leadership practices, workplace performance, and member support for organizational goals aspired in conflict conditions (Alhamani et al., 2020). An effective leader has high emotional intelligence and competency and can demonstrate transformational leadership behavior (Maqbool et al., 2017).

In crisis conditions, transformative leadership can drive the team to achieve organizational goals of how leaders can build staff commitment in supporting managers and people in pioneering change (Mahfouz et al., 2019). Members no longer work with standard work patterns but finding new ways to get out of the crisis. In this case, a leader needs to develop competencies for both individuals and teams in crisis management to overcome various types of crises to return to normal organizational conditions (Mahfouz et al., 2019), with transformative leadership, the leader can have a positive impact on organizational learning and knowledge sharing (Khan \& Khan, 2019).

In crisis management, the most powerful factor in having an impact on crisis management is the ability of the organization to organize various programs. These findings are consistent with how predetermined task-oriented leadership behavior has the highest level of impact on the effectiveness of crisis management (Kapucu \& Ustun, 2018). In this condition, the organization has tried to learn from the crisis and has developed and defined a kind of "action plan" for future problems related to crisis management (Dos et al., 2016). In a crisis, there is no much time to identify and consider options. The implementation of carefully considered contingency plans means the members and other stakeholders are alert regarding what to do, and who should do it (Smith \& Riley, 2012). Organizations with high reliability are more able to execute tasks in preventing a crisis (Bundy et al., 2017).

\section{Conclusions}

The impact of the COVID-19 pandemic has significantly changed and knocked the bottom out of education structures. The principal's leadership role is to manage a crisis and bring the school to a normal point and the system back into harmony. Different types of leadership will be more effective in different conditions. This study indicates that transformational leadership has a significant positive effect and a strong relationship in crisis management. Essentially, the leader's ability to drive all organization members to work together towards the organization's vision out of crisis becomes the critical factor. In contrast, in crisis management, the most decisive factor in managing a crisis is the ability to organize and execute various high-reliability programs rapidly. 


\section{Limitations and Implications for Future Studies}

Based on the research findings, the rules addressed are related to the principal and crisis management's leadership type. The population size is still within the school unit's scope to be enlarged by involving several schools in one province or country. The demographic data has not been used as a mediating variable in seeing the influence of leadership and crisis management, even though demographic data have been presented. Research related to crisis management is a very interesting topic since it is different from time to time, ranging from crisis impacts, conflict impacts, internal organizational problems, global economic conditions, natural disasters, conflicts, wars, and other conditions or internal organizational issues. Further research can enrich from various backgrounds and various effects of the crisis. It can involve mediator variables in exploring transformational leadership in crisis. It can be explored more deeply how transformative leadership works in managing crises in qualitative analysis to enrich the findings in the practical leadership topic in dealing with the crisis.

\section{References}

Agung, A., Widyani, D., Landra, N., Sudja, N., Ximenes, M., \& Sarmawa, I. W. G. (2020). The role of ethical behavior and entrepreneurial leadership to improve organizational performance Cogent Business \& Management, 7(1). https://doi.org/10.1080/23311975.2020.1747827

Al Khajeh, E. H. (2018). Leadership styles on organizational performance. Journal of Human Reseources Management Research, 1-10. https://doi.org/10.5171/2018.687849

Alhamani, N. M., Ismail, W. K. W., Kamarudin, S., \& Abdullah, F. Z. (2020). Linking emotional intelligence and transformational leadership to job Performance in a conflict-stricken environment. Talent Development \& Excellence, 12(3s), 2153-2163.

Ali, M., \& Mohammed, A. (2018). Transformational leadership and successful practices during crisis time: an exploratory case study in the context of a private university in Dubai. [Dissertations thesis for Management Leadership and Policy (MLP), The British University in Dubai]. https://bspace.buid.ac.ae/handle/1234/1330

Alzoubi, R. H., \& Jaaffar, A. H. (2020). The mediating effect of crisis management on leadership styles and hotel performance in Jordan. International Journal of Financial Research, 11(4), 384-397. https://doi.org/10.5430/ijfr.v11n4p384

Alzoubi, R. H. M., \& Jaaffar, A. H. (2020). Leadership styles, crisis management, and hotel performance A conceptual perspective of the Jordanian hotel. Journal of Critical Review, 7, 556-562. https://doi.org/10.31838/jcr.07.10.110

Ayoub, H. (2017). The role of effective leadership styles in crisis managment: A study of erbil, Iraq. International Journal of Economics, Commerce and Management, V(4), 107-121. http:// ijecm.co.uk/wp-content/uploads/2017/04/548a.pdf 
Bass, B., \& Avolio, B. (1994). Improving organizational effectiveness through transformational leadership. Thousand Oaks: Sage.

Bowers, M. R., Hall, J. R., \& Srinivasan, M. M. (2017). Organizational culture and leadership style: The missing combination for selecting the right leader for effective crisis management. Business Horizons, 60(4), 551-563. https://doi.org/10.1016/j.bushor.2017.04.001

Bundy, J., Pfarrer, M. D., Short, C. E., \& Coombs, W. T. (2017). Crises and crisis management: Integration, interpretation, and research development. In Journal of Management, 43(6), 1661-1692. https://doi.org/10.1177/0149206316680030

Chin, W. W. (1998). The partial least squares approach for structural equation modeling. Modern Methods For Business Research. In G. A. Marcoulides (Ed.), Methodology for business and management (pp. 295-336). NJ: Lawrence Erlbaum Associates.

Chin, Wynne W. (1998). The partial least squares approach to structural modeling. Modern Methods for Business Research, 295(2), 295-336.

Cho, Y., Shin, M., Billing, T. K., \& Bhagat, R. S. (2019). Transformational leadership, transactional leadership, and affective organizational commitment : A closer look at their relationships in two distinct national contexts. Asian Business \& Management, 0123456789. https://doi. org/10.1057/s41291-019-00059-1

Daniëls, E., Hondeghem, A., \& Dochy, F. (2019). A review on leadership and leadership development in educational settings. Educational Research Review, 14(2), https://doi. org/10.1016/j.edurev.2019.02.003.

Dos Santos, R. A. S., Mello, R. B.-, \& Cunha, C. J. C. de A. (2016). The leadership process during an organizational crisis. Journal of Operations and Supply Chain Management, 9(1), 94-109. https://doi.org/10.12660/joscmv9n1p94-109

Dwivedi, Y. K., Hughes, D. L., Coombs, C., Constantiou, I., Duan, Y., Edwards, J. S., Gupta, B., Lal, B., Misra, S., Prashant, P., Raman, R., Rana, N. P., Sharma, S. K., \& Upadhyay, N. (2020). Impact of COVID-19 pandemic on information management research and practice: transforming education, Work and life. International Journal of Information Management, 55, 102211. https://doi.org/10.1016/j.ijinfomgt.2020.102211

Ee, O., Halim, H. A., \& Ramayah, T. (2013). The effects of partnership quality on business process outsourcing success In Malaysia: Key users perspective. Service Business, 7(2), 227-253.

Esmer, Y., \& Dayi, F. (2016). Entrepreneurial leadership: A theoretical research. Proceeding 25th International Academic Conference, OECD Headquarters. Paris. https://doi.org/10.20472/ IAC.2016.025.020

Fors Brandebo, M. (2020). Destructive leadership in crisis management. Leadership and Organization Development Journal, 41(4), 567-580. https://doi.org/10.1108/LODJ-02-20190089

Grabo, A., Spisak, B. R., \& van Vugt, M. (2017). Charisma as signal: An evolutionary perspective on charismatic leadership. Leadership Quarterly, 28(4), 473-485. https://doi.org/10.1016/j. leaqua.2017.05.001 
Grabo, A., \& van Vugt, M. (2016). Charismatic leadership and the evolution of cooperation. Evolution and Human Behavior, 37(5), 399-406. https://doi.org/10.1016/j.evolhumbehav.2016.03.005

Hair, J. F., Hult, G. T. M., Ringle, C., \& Sarstedt, M. (2014). A primer on partial least squares structural equation modeling (PLS-SEM)tle. SAGE Publications, Incorporated.

Halverson, S. K., Murphy, S. E., \& Riggio, R. E. (2004). Charismatic leadership in crisis situations: A laboratory investigation of stress and crisis. Small Group Research, 35(5), 495-514. https:// doi.org/10.1177/1046496404264178

Hamid, Ramda S. \& Anmwar, S. M. (2019). Struktural equation modeling (SEM) berbasis varian. PT. Inkubator Penulis Indonesia.

Hamidovic, H. (2012). An introduction to crisis management. ISACA Journal, 5, 1-3. https://doi. org/10.1057/9780230363168_1

Hargreaves, A., \& Fullan, M. (2020). Professional capital after the pandemic: Revisiting and revising classic understandings of teachers' work. Journal of Professional Capital and Community, 5, 3-4. https://doi.org/10.1108/JPCC-06-2020-0039

Harris, A., \& Jones, M. (2020). COVID 19-School leadership in disruptive times. School Leadership and Management, 40(4), 243-247. https://doi.org/10.1080/13632434.2020.1811479

Harwati, L. N. (2013). Crisis management: Determining specific strategies. Asian Journal of Management Sciences and Education, 2(2), 170-181.

Henseler, J., Ringle, C. M., \& Sinkovics, R. R. (2009). The use of partial least squares path modeling in international marketing (AIM), Advance in International Marketing, 20, 277-320.

Hidayat, D., Anisti, Purwadhi, \& Wibawa, D. (2020). Crisis management and communication experience in education during the COVID-19 pandemic in Indonesia. Jurnal Komunikasi: Malaysian Journal of Communication, 36(3), 67-82. https://oi.org/10.17576/ JKMJC-2020-3603-05

Iii, N. B. T., Rawson, J. V., Slade, C. P., Bledsoe, M., \& Rn, M. (2018). Transformation and transformational leadership : A review of the current and relevant literature for academic radiologists. Academic Radiology, 8, 1-8. https://doi.org/10.1016/j.acra.2016.01.010

Jensen, U. T., Andersen, L. B., Bro, L. L., Bøllingtoft, A., Louise, T., Eriksen, M., Holten, A., Jacobsen, C. B., Ladenburg, J., Nielsen, P. A., Salomonsen, H. H., Westergård-nielsen, N., \& Würtz, A. (2016). Conceptualizing and measuring transformational and transactional leadership, 51(1), 3-33. https://doi.org/10.1177/0095399716667157

Jeremy Mitonga-Monga. (2012). Perceived leadership style and employee participation in a manufacturing company in the democratic republic of Congo. African Journal of Business Management, 6(15), 5389-5398. https://doi.org/10.5897/ajbm11.2443

Kapucu, N., \& Ustun, Y. (2018). Collaborative crisis management and leadership in the public sector. International Journal of Public Administration, 41(7), 548-561. https://doi.org/10.108 0/01900692.2017.1280819

Karim, A. J. (2016). The Indispensable styles, characteristics and skills for charismatic leadership in times of crisis. International Journal of Advanced Engineering, Management and Science (IJAEMS), 2(5), 363-372. 
Khan, N. A., \& Khan, A. N. (2019). What followers are saying about transformational leaders fostering employee innovation via organisational learning, knowledge sharing and social media use in public organisations? Government Information Quarterly, 36(4), 101391. https:// doi.org/10.1016/j.giq.2019.07.003

König, J., Jäger-Biela, D. J., \& Glutsch, N. (2020). Adapting to online teaching during COVID-19 school closure: Teacher education and teacher competence effects among early career teachers in Germany. European Journal of Teacher Education, 43(4), 608-622. https://doi.org/10.108 0/02619768.2020.1809650

Liu, Y., \& Froese, F. J. (2020). Crisis management, global challenges, and sustainable development from an asian perspective. Asian Business and Management, 19(3), 271-276. https://doi. org/10.1057/s41291-020-00124-0

Lovelace, B., Neely, B. H., Allen, J. B., \& Hunter, S. T. (2018). Charismatic, ideological , \& pragmatic ( CIP ) model of leadership : A critical review and agenda for future research. The Leadership Quarterly, 30(1), 96-110.https://doi.org/10.1016/j.leaqua.2018.08.001

Mahfouz, S. A., Awang, Z., \& Muda, H. (2019). The impact of transformational leadership on employee commitment in the construction industry. International Journal of Innovation, Creativity and Change, 7(10), 151-167.

Maqbool, R., Sudong, Y., Manzoor, N., \& Rashid, Y. (2017). The impact of emotional intelligence, project managers' competencies, and transformational leadership on project success: an empirical perspective. Project Management Journal, 48(3), 58-75. https://doi. org/10.1177/875697281704800304

Mitchelmore, S. \& Rowley, J. (2010). Entrepreneurial competencies: a literature review and development agenda. International Journal of Entrepreneurial Behaviour \& Research, 16(2), 92-111. doi: 10.1108/13552551011026995.

Oterkiil, C., \& Ertesva, S. K. (2014). Development af a measurement for transformational and transactional leadership in schools taking an a school-based intervention, 42(5), 5-27. https:// doi.org/10.1177/1741143214523011

Pihie, Z. L. (2017). Conceptualization of entrepreneurial leadership models and its suitability towards educational settings, International Journal of Humanities Social Sciences and Education, 4(11), 153-158.

Plessis, D. Du, \& Keyter, C. (2020). Suitable leadership for the Covid -19 converged crisis, Africa Journal of Public Sector Development and Governance 3(1), 61-73. https://hdl.handle.net/10520/ ejc-ajpsdg-v3-n1-a3

Salvador, A. B., Ikeda, A. A., \& Crescitelli, E. (2017). Crisis management and its impact on brand image. Gestao e Producao, 24(1), 15-24. https://doi.org/10.1590/0104-530X1668-14

Sang, S., Lee, J. D., \& Lee, J. (2010). E- government adoption in Cambodia: a Partial least squares approach. Transforming government: People title. Process and Policy, 4(2), 138-157. https:// doi.org/doi:10.1108/17506161011047370

Shao, Z., Feng, Y., \& Wang, T. (2017). Charismatic leadership and tacit knowledge sharing in the context of enterprise systems learning: The mediating effect of psychological safety climate 
and intrinsic motivation. Behaviour and Information Technology, 36(2), 194-208. https://doi. org/10.1080/0144929X.2016.1221461

Shrivastava, P., Mitroff, I., \& Alpaslan, C. M. (2013). Imagining an education in crisis management. Journal of Management Education, 37(1), 6-20. https://doi.org/10.1177/1052562912455418

Silva, A. (2016). What is leadership? Journal of Business Studies Quarterly, 8(1), 1-6.

Smith, L., \& Riley, D. (2012). School leadership in times of crisis. School Leadership and Management, 32(1), 57-71. https://doi.org/10.1080/13632434.2011.614941

Taneja, S., Pryor, M., Sewell, S., \& Recuero, A. (2014). Strategic crisis management: A basis for renewal and crisis prevention. Journal of Management Policy and Practice, 15(1), 78.

Taormina, R. J., \& Taormina, R. J. (2008). Interrelating leadership behaviors, organizational organizational culture. Leadership \& Organization Development Journal, 29 (1), 85-102. https://doi.org/10.1108/01437730810845315

Teo, W. L., Lee, M., \& Lim, W. S. (2017). The relational activation of resilience model: How leadership activates resilience in an organizational crisis. Journal of Contingencies and Crisis Management, 25(3), 136-147. https://doi.org/10.1111/1468-5973.12179

Thornberry, N. (2006). Lead like an entrepreneur. McGraw Hill Professional.

Turnnidge, J., \& Côté, J. (2016). Applying transformational leadership theory to coaching research in youth sport: A systematic literature review. International Journal of Sport and Exercise Psychology, 16 (3), 327-342. https://doi.org/10.1080/1612197X.2016.1189948

Urbach, N., \& Ahlemann, F. (2010). Structural equation modeling in information systems research using partial least squares. Journal of Information Technology Theory and Application, 11(2), 5-40.

van Wart, M., \& Kapucu, N. (2011). Crisis management competencies: The case of emergency managers in the USA. Public Management Review, 13(4), 489-511. https://doi.org/10.1080/ 14719037.2010.525034

Wahab, A., \& Tyasari, I. (2020). Asia pacific management review entrepreneurial leadership for university leaders : A futuristic approach for Pakistani. Asia Pacific Management Review, 25(1), 54-63. https://doi.org/10.1016/j.apmrv.2019.09.002

Javidan, M., \& Waldman, D. A. (2003). Exploring charismatic leadership in the public sector: Measurement and consequences. Public Administration Review, 63(2), 229-242. https://doi. org/10.1111/1540-6210.00282

Weihrich, H., Cannice, M. V., \& Koontz, H. (2008). No titmanagement (12th ed.). New Delhi: Mc Graw Hill.

Whitla, M. E. (2003). Crisis management and the school community. VIC: ACER Press.

Williams, T. A., Gruber, D. A., Sutcliffe, K. M., Shepherd, D. A., \& Zhao, E. Y. (2017). Organizational response to adversity: Fusing crisis management and resilience research streams. Academy of Management Annals, 11(2), 733-769. https://doi.org/10.5465/annals.2015.0134

Wino, D., Utomo, F., Hanita, M., Kajian, S., \& Indonesia, U. (2020). Covid-19 Untuk Memastikan Ketahanan Nasional [Crisis Leadership Strategy in Combating Covid-19 Pandemic To Ensure 
National Resilience]. Jurnal Lemhannas, 8(2), 208-226. http://jurnal.lemhannas.go.id/index. php/jkl/article/download/83/87/

Zhang, Z., Jia, M., \& Gu, L. (2012). Transformational leadership in crisis situations: Evidence from the people's republic of China. International Journal of Human Resource Management, 23(19), 4085-4109. https://doi.org/10.1080/09585192.2011.639027

\section{List of Appendixes}

\section{Table 1}

Descriptive Statistics of Each Item in Each Variable $(n=100)$

\begin{tabular}{|c|c|c|c|}
\hline Item \& Variable & $\begin{array}{l}\text { Loading } \\
\text { Factor }\end{array}$ & Mean & SD \\
\hline TRF 1 & 0.788 & 4.140 & 0.860 \\
\hline TRF 2 & 0.794 & 4.010 & 0.877 \\
\hline TRF 3 & 0.776 & 4.120 & 0.828 \\
\hline TRF 4 & 0.833 & 3.930 & 0.908 \\
\hline TRF 5 & 0.750 & 3.960 & 0.948 \\
\hline TRF 6 & 0.774 & 4.040 & 0.859 \\
\hline TRF 7 & 0.772 & 3.830 & 1.030 \\
\hline Transformational leadership & & 4.004 & 0.901 \\
\hline TRSC 1 & 0.851 & 4.130 & 0.868 \\
\hline TRSC 2 & 0.770 & 3.740 & 0.955 \\
\hline TRSC 3 & 0.871 & 3.850 & 0.963 \\
\hline TRSC 4 & 0.900 & 3.840 & 0.902 \\
\hline Transactional leadership & & 3.890 & 0.922 \\
\hline CHAR 1 & 0.845 & 3.760 & 0.950 \\
\hline CHAR 2 & 0.850 & 3.560 & 0.993 \\
\hline CHAR 3 & 0.822 & 3.720 & 0.788 \\
\hline CHAR 4 & 0.806 & 3.630 & 0.997 \\
\hline CHAR 5 & 0.788 & 3.780 & 0.820 \\
\hline CHAR 6 & 0.838 & 3.720 & 0.873 \\
\hline CHAR 7 & 0.733 & 3.490 & 0.733 \\
\hline Charismatic leadership & & 3.666 & 0.879 \\
\hline ENTR 1 & 0.798 & 3.780 & 0.782 \\
\hline ENTR 2 & 0.827 & 3.830 & 0.837 \\
\hline
\end{tabular}




$\begin{array}{llll}\text { ENTR3 } & 0.762 & 4.100 & 0.768 \\ \text { ENTR 4 } & 0.768 & 4.110 & 0.733 \\ \text { ENTR 5 } & 0.866 & 3.750 & 1.052 \\ \text { ENTR 6 } & 0.803 & 3.650 & 0.876 \\ \text { ENTR 7 } & 0.883 & 3.810 & 0.891 \\ & & & \\ \text { Entrepreneurial leadership } & & 3.861 & 0.848 \\ \text { CRISIS 1 } & 0.806 & 3.870 & 0.844 \\ \text { CRISIS 2 } & 0.746 & 4.040 & 0.836 \\ \text { CRISIS 3 } & 0.799 & 3.890 & 0.760 \\ \text { CRISIS 4 } & 0.735 & 3.930 & 0.738 \\ \text { CRISIS 5 } & 0.815 & 3.710 & 0.765 \\ \text { CRISIS 6 } & 0.781 & 3.700 & 0.843 \\ \text { CRISIS 7 } & 0.808 & 3.510 & 0.911 \\ \text { Crisis Management } & & 3.807 & 0.818\end{array}$

Note: TRF: Transformative Leadership, TRSC: Transactional Leadership, CHAR: Charismatic Leadership, ENTR: Entrepreneurial Leadership, dan CRISIS: Crisis Management

\section{Table 3}

Cross Loading Among Variable $(n=100)$

\begin{tabular}{lccccc}
\hline & CHR X3 & CRIS Y & ENT X4 & TRF X1 & TRSC X2 \\
\hline CHAR 1 & 0.845 & 0.425 & 0.666 & 0.616 & 0.601 \\
CHAR 2 & 0.850 & 0.480 & 0.612 & 0.593 & 0.584 \\
CHAR 3 & 0.822 & 0.425 & 0.587 & 0.523 & 0.654 \\
CHAR 4 & 0.806 & 0.345 & 0.715 & 0.635 & 0.569 \\
CHAR 5 & 0.788 & 0.495 & 0.650 & 0.617 & 0.656 \\
CHAR 6 & 0.838 & 0.401 & 0.754 & 0.683 & 0.656 \\
CHAR 7 & 0.733 & 0.327 & 0.671 & 0.523 & 0.544 \\
CRISIS1 & 0.388 & 0.806 & 0.372 & 0.483 & 0.482 \\
CRISIS2 & 0.344 & 0.746 & 0.430 & 0.527 & 0.396 \\
CRISIS3 & 0.439 & 0.799 & 0.468 & 0.544 & 0.510 \\
CRISIS4 & 0.338 & 0.735 & 0.487 & 0.493 & 0.298 \\
CRISIS5 & 0.486 & 0.815 & 0.454 & 0.465 & 0.481 \\
CRISIS6 & 0.415 & 0.781 & 0.387 & 0.467 & 0.478 \\
CRISIS7 & 0.428 & 0.808 & 0.431 & 0.497 & 0.498 \\
ENTR1 & 0.692 & 0.411 & 0.798 & 0.675 & 0.581
\end{tabular}




\begin{tabular}{llllll} 
ENTR2 & 0.699 & 0.395 & 0.827 & 0.665 & 0.556 \\
ENTR3 & 0.474 & 0.441 & 0.762 & 0.609 & 0.460 \\
ENTR4 & 0.483 & 0.435 & 0.768 & 0.738 & 0.465 \\
ENTR5 & 0.849 & 0.530 & 0.866 & 0.746 & 0.685 \\
ENTR6 & 0.665 & 0.470 & 0.803 & 0.668 & 0.592 \\
ENTR7 & 0.746 & 0.440 & 0.883 & 0.730 & 0.682 \\
TRF 1 & 0.433 & 0.433 & 0.650 & 0.763 & 0.467 \\
TRF 2 & 0.492 & 0.416 & 0.682 & 0.788 & 0.499 \\
TRF 3 & 0.452 & 0.460 & 0.625 & 0.794 & 0.546 \\
TRF 4 & 0.594 & 0.585 & 0.586 & 0.776 & 0.648 \\
TRF 5 & 0.583 & 0.530 & 0.641 & 0.833 & 0.610 \\
TRF 6 & 0.576 & 0.451 & 0.672 & 0.750 & 0.546 \\
TRF 7 & 0.837 & 0.546 & 0.792 & 0.774 & 0.773 \\
TRSC1 & 0.661 & 0.516 & 0.603 & 0.723 & 0.851 \\
TRSC2 & 0.535 & 0.283 & 0.535 & 0.538 & 0.770 \\
TRSC3 & 0.635 & 0.541 & 0.615 & 0.643 & 0.871 \\
TRSC4 & 0.701 & 0.538 & 0.643 & 0.649 & 0.900 \\
\hline N & 0.54 TRF Trans
\end{tabular}

Note: TRF: Transformative Leadership, TRSC: Transactional Leadership, CHAR: Charismatic Leadership, ENTR: Entrepreneurial Leadership, dan CRISIS: Crisis Management

\section{Vadovavimo lyderystės stilių efektyvumas valdant krizes}

Eko Nurhaji Purnomo ${ }^{1}$, Achmad Supriyanto ${ }^{2}$, Mustiningsih $^{3}$, Zummy Anselmus Dami ${ }^{4}$

1 Malango valstybinis universitetas, Edukologijos fakultetas, Švietimo administravimo katedra, Rytų Java, Indonezija, ekonurhajila@yahoo.com

2. Malango valstybinis universitetas, Edukologijos fakultetas, Švietimo administravimo katedra, Rytų Java, Indonezija, a.supriyanto.fip@um.ac.id

3 Malango valstybinis universitetas, Edukologijos fakultetas, Švietimo administravimo katedra, Rytų Java, Indonezija,, mustiningsih.fip@um.ac.id

4 Malango valstybinis universitetas, Edukologijos fakultetas, Švietimo administravimo katedra, Rytų Java, Indonezija, zummydami82@gmail.com

\section{Santrauka}

Tyrimo tikslas - ištirti pagrindinio krizių valdymo mokykloje efektyvaus vadovavimo lyderystės stilius. Šiame straipsnyje analizuojami klausimai: 1) ar yra statistiškai reikšmingas ryšys tarp charizmatiško vadovavimo ir krizių valdymo; 2) ar yra statistiškai reikšmingas ryšys tarp verslumo lyderystès ir krizių valdymo; 3) ar yra statistiškai reikšmingas ryšys tarp 
transformuojančios lyderystės ir krizių valdymo; 4) ar yra statistiškai reikšmingas ryšys tarp transakcinès lyderystės ir krizių valdymo; 5) kuris vadovavimo stilius pasižymi stipriausiais santykiais valdant krizę. Tikrinamas charizmatiškas, verslus, transformuojantis ir transakcinis lyderystès stilius. Šiame tyrime dalyvavo Indonezijos Malango Tursinos Islamo internatinès mokyklos mokytojai ir administracijos atstovai. Tyrimo imtis buvo atrinkta naudojant sistemingą atsitiktinę atranką, ją sudarè 100 mokytojų ir 325 mokymo administracijos atstovai. Duomenims rinkti buvo naudojama anketinè apklausa raštu, kur buvo pateikti standartizuoti klausimai. Duomenų analizė atlikta naudojant struktūrinių lygčių modeliavimą. Veiksmingiausi pagrindinio vadovavimo stiliaus kintamieji valdant krizę buvo apskaičiuoti naudojant „Smart PLS-SEM-3.0“. Šio tyrimo išvados parodè, kad transformuojanti lyderystė tureje stiprų teigiamą poveikị krizių valdymui, kai F2 vertẻ buvo 0,466, charizmatiška lyderystė ir transakcinè lyderystė turejjo teigiamą, bet silpną poveikị krizių valdymui, kai F2 vertè buvo 0,031 ir 0,215 . Priešingai, verslumo lyderystè krizių valdymui turẻjo neigiamą, bet silpną poveikį, kai F2 reikšmė buvo -0,021.

Esminiai žodžiai: charizmatiška lyderystè, verslumo lyderystè, transformuojanti lyderyste், transakciné lyderystè ir krizių valdymas.

Gauta 20201231 / Received 31122020

Priimta 20210219 / Accepted 19022021 